\title{
Integration of vegetation indices into a water balance model to estimate evapotranspiration of wheat and corn
}

\author{
F. L. M. Padilla, M. P. González-Dugo, P. Gavilán, and J. Domínguez \\ IFAPA, Centro Alameda del Obispo, P.O. Box 3092, Córdoba, Spain \\ Received: 20 October 2010 - Published in Hydrol. Earth Syst. Sci. Discuss.: 29 October 2010 \\ Revised: 1 April 2011 - Accepted: 6 April 2011 - Published: 12 April 2011
}

\begin{abstract}
Vegetation indices (VIs) have been traditionally used for quantitative monitoring of vegetation. Remotely sensed radiometric measurements of visible and infrared solar energy, which is reflected or emitted by plant canopies, can be used to obtain rapid, non-destructive estimates of certain canopy attributes and parameters. One parameter of special interest for water management applications, is the crop coefficient employed by the FAO-56 model to derive actual crop evapotranspiration (ET). The aim of this study was to evaluate a methodology that combines the basal crop coefficient derived from VIs with a daily soil water balance in the root zone to estimate daily evapotranspiration rates for corn and wheat crops at field scale. The ability of the model to trace water stress in these crops was also assessed. Vegetation indices were first retrieved from field hand-held radiometer measurements and then from Landsat 5 and 7 satellite images. The results of the model were validated using two independent measurement systems for ET and regular soil moisture monitoring, in order to evaluate the behavior of the soil and atmosphere components of the model. ET estimates were compared with latent heat flux measured by an eddy covariance system and with weighing lysimeter measurements. Average overestimates of daily ET of 8 and $11 \%$ were obtained for corn and wheat, respectively, with good agreement between the estimated and measured root-zone water deficit for both crops when field radiometry was employed. When the satellite sensor data replaced the field radiometry data the overestimation figures slightly changed to 9 and $6 \%$ for the same two crops. The model was also used to monitor the water stress during the 2009 growing season, detecting several periods of water stress in both crops. Some of these stresses occurred during stages like grain filling, when
\end{abstract}

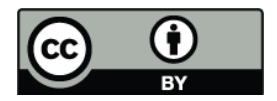

Correspondence to: F. L. M. Padilla (franciscol.munoz@juntadeandalucia.es) the water stress is know to have a negative effect on yield. This fact could explain the lower yield reached compared to local yield statistics for wheat and corn. The results showed that the model can be used to calculate the water requirements of these crops in irrigated areas and that its ability to monitor water stress deserves further research.

\section{Introduction}

Recent studies have shown that the global demand for food will increase for at least another $40 \mathrm{yr}$. It is estimated that the global population will reach nine billion people by the middle of this century (Charles et al., 2010). One consequence of the rapid growth in world population is that the pressure on water resources is increasing (Rijsberman, 2006). In the future, less water will be available for agricultural production as a result of competition with the industrial and domestic sectors. At the same time, food production will need to increase to feed the growing population (FAO, 2006). In arid and semi-arid regions, the very availability of water is a major limitation on crop production due to insufficient rainfall to compensate for the evaporative losses of crops. Improvements in water management in irrigated areas and adequate irrigation scheduling are essential, not only to improve water productivity, but also to increase the sustainability of irrigated agriculture (Hsiao et al., 2007). One of the most important components of the water balance is evapotranspiration (ET), i.e. the water transferred to the atmosphere by soil evaporation and plant transpiration. Several techniques, such as Bowen ratio energy balance, eddy covariance and weighing lysimeters, provide ET measurements, but these are expensive, they are limited to point or small experimental field scales and can only be fully exploited by trained research personnel (Allen et al., 1998). Several studies have evaluated

Published by Copernicus Publications on behalf of the European Geosciences Union. 
remote sensing techniques for estimating crop evapotranspiration on a large scale (Anderson et al., 2007; GonzálezDugo and Mateos, 2008; Teixeira et al., 2009). In the course of the past few decades, besides advances in sensor development, several methodologies for incorporating optical and thermal remote-sensing data into energy and water balance models have been developed, producing estimates of actual ET (Kustas and Norman, 1999; Allen et al., 2007; Neale et al., 1989). These remote sensing approaches provide an opportunity to extend the area of application of these models from point to basin or regional scales, producing a better representation of vegetation heterogeneity.

The current limited availability of high-resolution thermal satellite sensors hinders their use in irrigation scheduling and water management at field scales, and thus underlines the importance of models based on readily available optical data as a more plausible option for these applications. This approach is usually based on the FAO-56 method, which represents ET as a product of a reference evapotranspiration value $\left(\mathrm{ET}_{\mathrm{o}}\right)$, which takes atmospheric demands into account, and a crop coefficient that considers the characteristics of the crop (Doorenbos and Pruitt, 1977; Allen et al., 1998). The crop coefficient can be calculated using a single method that combines the effect of crop transpiration and soil evaporation into a unique coefficient $\left(K_{\mathrm{c}}\right)$, or a dual one that separates the plant transpiration, represented by a basal crop coefficient $\left(K_{\mathrm{cb}}\right)$ and the soil evaporation coefficient $\left(K_{\mathrm{e}}\right)$. The single model is widely used because it requires only phenological information and standard meteorological data to produce acceptable estimated ET values (Er-Raki, 2007). The dual model is mainly oriented towards research and real-time irrigation scheduling for high-frequency water applications (Allen et al., 1998). A great deal of research has been done in the course of the past $30 \mathrm{yr}$ on estimating the standard values and temporal evaluation of crop coefficients (Allen et al., 1998; Wright, 1982), which can be estimated from remote spectral measurements because both the basal crop coefficient and the vegetation indices are sensitive to ground cover fraction (fc) (Choudhury et al., 1994). This coefficient may be derived from multispectral vegetation indices (VI) obtained by remote sensing (Jackson et al., 1980; Heilman et al., 1982; Bausch and Neale, 1987; Neale et al., 1989; Calera et al., 2004). Some authors have suggested that relationships between $K_{\mathrm{cb}}$ and VI are linear (Bausch and Neale, 1987; Neale et al., 1989; Gonzalez-Piqueras et al., 2003), but others have found non-linear relationships (Hunsaker et al., 2003, 2005). These relationships have been studied for several crops and recently for potato (Jayanthi et al., 2007), cotton and sugarbeet (González-Dugo and Mateos, 2008), wheat (Duchemin et al., 2006; Er-Raki et al., 2007) and grapes (Campos et al., 2010).

We used a combined methodology of basal crop coefficient derived from vegetation indices obtained initially from a hand-held radiometer and then from a series of satellite images and a daily water balance in the root zone of the crop.
This combined methodology enables us to calculate the daily corn and wheat crop coefficient and daily ET. A further objective was to determine the ability of the model to assess water stress in both crops. A validation was performed using field soil moisture measurements and two different instruments to measure ET; an eddy covariance system and a weighing lysimeter.

\section{Materials and methods}

\subsection{Description of the model}

The model used to estimate ET was developed in the Bajo-Guadalquivir Irrigation Scheme in southern Spain (González-Dugo and Mateos, 2008). Daily ET was computed using the dual approach in the form popularized by the FAO56 manual (Allen et al., 1998), combined with spectral data provided by remote sensors. A brief description of this approach is presented below and a complete explanation of the FAO model can be found in Allen et al. (1998).

Crop transpiration, represented by the basal crop coefficient, $K_{\mathrm{cb}}$, is separated from soil surface evaporation as follow:

$\mathrm{ET}_{c}=\left(K_{\mathrm{cb}} K_{\mathrm{s}}+K_{\mathrm{e}}\right) \mathrm{ET}_{\mathrm{o}}$

Reference evapotranspiration $\left(\mathrm{ET}_{\mathrm{o}}, \mathrm{mm} \mathrm{d}^{-1}\right)$ was estimated using the Penman-Monteith equation (Allen et al., 1998), with daily solar radiation, air temperature, wind speed, and relative humidity data supplied by weather stations. The water stress coefficient, $K_{\mathrm{S}}$, quantifies the reduction in crop transpiration due to soil water deficit, where $K_{\mathrm{s}}=1$ for non-stress conditions and $K_{\mathrm{s}}<1$ when there is a shortage of water in the root zone. $K_{\mathrm{e}}$ is the soil evaporation coefficient that describes the evaporative component of $\mathrm{ET}_{\mathrm{c}}$. The procedure for calculating each coefficient is described below.

\subsubsection{Basal crop coefficient}

The $K_{\mathrm{cb}}$ in Eq. (1) may be derived from multispectral vegetation indices obtained by remote sensing. VIs are transformations of two or more spectral bands designed to assess vegetation condition, foliage, cover, phenology and processes related to the fraction of photosynthetically active radiation absorbed by a canopy (fPAR) (Asrar et al., 1989; Baret et al., 1991; Glenn et al., 2008) VIs are also essential tools in land-cover classification, climate and land-use-change detection, drought monitoring and habitat loss, to name just a few applications (Glenn et al., 2008). SAVI (Soil Adjusted Vegetation Index, Huete, 1988) is one of the most used indices highlighting the ability of the index to minimize the effect of the soil on vegetation quantification. It was taken into account due to the positive results obtained in previous work (González-Dugo and Mateos, 2008). The SAVI index was calculated as follow: 
Table 1. Crop parameter values used for deriving the crop coefficients and computing the water balance following the procedure described in FAO Irrigation and Drainage Paper No. 56 (Allen et al., 1998).

\begin{tabular}{l|rr|r}
\hline & \multicolumn{2}{|c|}{ Corn } & Wheat \\
Parameter & 2008 & 2009 & 2009 \\
\hline Maximum crop height (m) & 2.6 & 2.6 & 0.92 \\
Maximum effective root depth (m) & 1.35 & 1.35 & 1.25 \\
Minimun effective root depth (m) & 0.3 & 0.3 & 0.3 \\
SAVI $_{\max }$ & 0.65 & 0.65 & 0.7 \\
SAVI $_{\min }$ & 0.07 & 0.07 & 0.09 \\
Maximum basal crop coefficient & 1.11 & 1.13 & 1.06 \\
K $_{\text {cbmax }}$ ) & & & \\
Ground cover fraction for $\mathrm{K}_{\text {cbmax }}$ & 80 & 80 & 80 \\
\hline
\end{tabular}

${ }^{\text {a }}$ Typical values adjusted for local relative humidity and wind speed.

$\mathrm{SAVI}=\frac{\left(\rho_{\mathrm{NIR}}-\rho_{\mathrm{red}}\right)}{\left(\rho_{\mathrm{NIR}}+\rho_{\mathrm{red}}+L\right)}(L+1)$

where $\rho_{\text {NIR }}$ and $\rho_{\text {red }}$ are the reflectance in the near-infrared and red spectra, respectively, and $L$ is a soil normalization factor, generally taken to be 0.5 (Huete, 1988).

An equation described by González-Dugo et al. (2009) to compute the basal crop coefficient $\left(K_{\mathrm{cb}}\right)$ from SAVI was used in this study:

$$
\begin{aligned}
K_{\mathrm{cb}} & =\frac{K_{\mathrm{cbmax}}}{f_{\mathrm{cbmax}}}\left(\frac{\mathrm{SAVI}-\mathrm{SAVI}_{\min }}{\mathrm{SAVI}_{\max }-\mathrm{SAVI}_{\min }}\right) \text { if } f_{\mathrm{c}}<f_{\mathrm{cmax}} \\
K_{\mathrm{cb}} & =K_{\mathrm{cb} \max } \text { if } f_{\mathrm{c}} \geq f_{\mathrm{cmax}}
\end{aligned}
$$

where $f_{\mathrm{cmax}}$ is the ground-cover fraction $\left(f_{\mathrm{c}}\right)$ at which $K_{\mathrm{cb}}$ is at its maximum ( $\left.K_{\text {cbmax }}\right)$, and the subscripts max and min of SAVI refer to the values for very large LAI and bare soil, respectively. The values adopted in the model are derived from field measurements, and can be found in Table 1. The change over time in SAVI for each field throughout the growing season was calculated by linear interpolation of the SAVI values obtained by remote sensors.

\subsubsection{Water stress coefficient}

A soil root-zone water balance was calculated by keeping track of the main incoming and outgoing water fluxes at the boundaries of the root zone in order to calculate $K_{\mathrm{S}}$ in Eq. (1). The root-zone depth $\left(Z_{\mathrm{r}}\right)$ was calculated as a function of $K_{\mathrm{cb}}$.

$Z_{\mathrm{r}}=Z_{\mathrm{rmin}}+\left(Z_{\mathrm{rmax}}-Z_{\mathrm{rmin}}\right) \frac{K_{\mathrm{cb}}}{K_{\mathrm{cb} \max }}$

where $Z_{\text {rmax }}$ and $Z_{\text {rmin }}$ are the maximum effective root depth and the effective root depths during the early stages of crop growth (Table 1). The minimum effective root depth is treated here as the depth of the soil layer from which the seed can extract water to germinate, and a value of $0.3 \mathrm{~m}$ was adopted. The change in the root zone water content, $\Delta S_{\mathrm{W}}$, was calculated as the difference between the water inflows and outflows.

$\Delta S_{\mathrm{W}}=S_{\mathrm{wf}}-S_{\mathrm{wi}}=R-\mathrm{ET}-D$

where $S_{\mathrm{wf}}$ and $S_{\mathrm{wi}}(\mathrm{mm})$ are the root-zone water content at the beginning and end of the water balance period, respectively. $R$ is infiltrated rainfall and $D$ is deep drainage, both during the water balance period. Equation (7) may be expressed in terms of root-zone water deficit, calculated daily:

$\mathrm{RZWD}_{i}=\mathrm{RZWD}_{i-1}+\mathrm{ET}_{i}+D_{i}-R_{i}$

where the subscript $\mathrm{i}$ indicates a given day and $\mathrm{RZWD}_{i}$ and $\mathrm{RZWD}_{i-1}$ are the root-zone water deficits on day $i$ and $i-1$, respectively.

It is understood that the root zone is full of water, $\mathrm{RZWD}=0$, when its water content is at field capacity, and that it is empty when the water content reduces plants to the wilting point. The root-zone water-holding capacity (RZWHC) is the depth of water between these two extremes:

$\mathrm{RZWHC}=1000\left(\theta_{\mathrm{fc}}-\theta_{\mathrm{wp}}\right) Z_{\mathrm{r}}$

where $\theta_{\mathrm{fc}}$ is the water content at field capacity $\left(\mathrm{m}^{3} \mathrm{~m}^{-3}\right), \theta_{\mathrm{wp}}$ is the water content at wilting point $\left(\mathrm{m}^{3} \mathrm{~m}^{-3}\right)$, and $Z_{\mathrm{r}}$ is the rooting depth $(\mathrm{m})$.

The stress coefficient, $K_{\mathrm{s}}$, is calculated on the basis of the relative root-zone water deficit as:

$K_{\mathrm{S}}=\frac{\mathrm{RZWHC}^{-\mathrm{RZWD}_{i}}}{(1-p) \mathrm{RZWHC}}$ if $\mathrm{RZWD}_{i}<(1-p) \mathrm{RZWHC}^{-}$

$K_{\mathrm{S}}=1$ if $\mathrm{RZWD}_{i}>(1-p) \mathrm{RZWHC}$

where $p$ is the fraction of the RZWHC below which transpiration is reduced as a consequence of water deficit. According to the FAO-56 manual, the recommended $p$ value is 0.55 for corn, winter and spring wheat when $\mathrm{ET}_{\mathrm{c}}$ is $5 \mathrm{~mm}$ per day. The value for $p$ was adjusted for different values of $\mathrm{ET}_{\mathrm{c}}$, using the following approximation:

$p=0.55+0.04\left(5-\mathrm{ET}_{\mathrm{c}}\right)$

\subsubsection{Soil evaporation coefficient}

The estimation of $K_{\mathrm{e}}$ requires the daily water balance of the soil surface evaporation layer, of effective depth equal to $Z_{\mathrm{e}}$, to be calculated. The evaporation coefficient is at its maximum when the topsoil is wet following rain or irrigation, and is zero when the soil surface is dry and no water remains near the soil surface for evaporation. $K_{\mathrm{e}}$ is calculated as:

$K_{\mathrm{e}}=K_{\mathrm{r}}\left(K_{\mathrm{cmax}}-K_{\mathrm{cb}}\right)$

where $K_{\mathrm{r}}$ is a dimensionless evaporation reduction coefficient that depends on the cumulative depth of water depleted from the topsoil and $K_{\mathrm{cmax}}$ is the maximum value of $K_{\mathrm{c}}$ following rainfall or irrigation. Since evaporation is restricted at 
Table 2. Soil parameter values used for computing the water balance following the procedure described in Allen et al. (1998), being $\theta_{\mathrm{FC}}$ the soil water content at field capacity, $\theta_{\mathrm{WP}}$ the soil water content at wilting point, $Z_{\mathrm{e}}$ the depth of soil surface evaporation layer, REW the readily evaporable water and TEW the total evaporable water.

\begin{tabular}{lrrrrr}
\hline Parameter & $\theta_{\mathrm{FC}}\left(\mathrm{m}^{3} \mathrm{~m}^{-3}\right)$ & $\theta_{\mathrm{WP}}\left(\mathrm{m}^{3} \mathrm{~m}^{-3}\right)$ & $Z_{\mathrm{e}}(\mathrm{m})$ & $\mathrm{REW}(\mathrm{mm})$ & $\mathrm{TEW}(\mathrm{mm})$ \\
\hline Corn (2008-2009) & 0.255 & 0.09 & 0.1 & 10 & 21 \\
Wheat (2009) & 0.23 & 0.085 & 0.1 & 10 & 18.78 \\
\hline
\end{tabular}

any moment by the energy available at the exposed soil fraction, the value of $K_{\mathrm{e}}$ cannot exceed the product $f_{\mathrm{ew}} \times K_{\mathrm{cmax}}$, where $f_{\text {ew }}$ is the fraction of the soil surface not covered by vegetation and wetted by irrigation or precipitation (Allen et al., 1998).

The soil evaporation can be assumed to take place in two stages: an energy-limiting stage, and a falling-rate stage. $K_{\mathrm{r}}$ can thus be estimated as:

$K_{\mathrm{r}}=1$ if $D_{\mathrm{e}, i-1} \leq \mathrm{REW}$

$K_{\mathrm{r}}=\frac{\mathrm{TEW}-\mathrm{D}_{\mathrm{e}, i-1}}{\mathrm{TEW}-\mathrm{REW}}$ if $D_{\mathrm{e}, i-1}>\mathrm{REW}$

where $D_{\mathrm{e}, i-1}$ is the cumulative depth of evaporation from the soil surface layer at the end of day $i-1$. TEW, the total evaporable water, is equal to the maximum depth of water that can be evaporated from the soil during a complete drying cycle, and the readily evaporable water, REW, is the maximum depth of water that can be evaporated from the topsoil layer without restriction during the energy-limiting stage.

It is assumed that shortly following a major wetting event, the water content of the evaporation layer is at field capacity, $\theta_{\mathrm{fc}}$, and the soil can dry to a water content level that is halfway between oven dry and wilting point, $\theta_{\mathrm{wp}}$. The total evaporable water can be then estimated as (Allen et al., 1998):

$\mathrm{TEW}=1000\left(\theta_{\mathrm{fc}}-0.5 \theta_{\mathrm{wp}}\right) Z_{\mathrm{e}}$

\subsection{Description of experimental sites and model input data}

\subsubsection{Site description}

Two experimental sites grown with wheat (Triticum aestivum) and corn (Zea mays) were monitored during the 2008 (corn) and 2009 (corn and wheat) growing seasons (Fig. 1). Two contiguous drip-irrigated corn fields were selected in the Bembézar Irrigation Scheme of Hornachuelos (Province of Cordoba, southern Spain) for the consecutive field measurement campaigns. Both fields were large enough, 8 and 7.4 ha, respectively, to be clearly observed by a satellite remote sensor with a spatial resolution of $30 \mathrm{~m}$, thus avoiding edge effects. The planting dates were 7 March 2008 and 5 March 2009 respectively, and PR31D58 corn was used in both seasons. Finally, the two fields were mechanically harvested on 17 September 2008 and 1 September 2009, respectively. The second site was a rainfed bread wheat field of 1.5 ha, located in the IFAPA Alameda del Obispo (City of Cordoba) experimental farm, where a weighing lysimeter has been in operation since 1985 . It was planted on 19 December 2008 with the Lubrican cultivar and harvested on 3 July 2009. The Mediterranean climate of this area is characterized by an annual average precipitation of around $600 \mathrm{~mm}$, very dry summers and average air temperatures of $10^{\circ} \mathrm{C}$ in winter and $27^{\circ} \mathrm{C}$ during the summer. For the period of interest, from planting to harvest date on 2009 wheat season, $301 \mathrm{~mm}$ of precipitation and an average air temperature of $15^{\circ} \mathrm{C}$ were measured. The corresponding figures for the 2008 and 2009 corn seasons were 356 and $101 \mathrm{~mm}$, and 22 and $23^{\circ} \mathrm{C}$, respectively.

Soil properties such as texture and depth were measured in the wheat field and in one of the corn fields. Soil water content at field capacity and wilting point were derived from texture data using the Rosetta pedotransfer function model (Schapp et al., 2001). The same water content limits were used for both corn fields, in view of their close proximity and the similarity of their soil types.

Soil and crop parameters values used in the model applications are listed in Tables 1 and 2 respectively. Soil parameters such as the depth of soil surface evaporation layer $\left(Z_{\mathrm{e}}\right)$, readily evaporable water (REW) and total evaporable water (TEW) were adapted from values tabulated in Allen et al. (1998).

The water balance computation was initialized on 1 September 2007 and 2008, for 2008 and 2009 corn seasons, and simulated under different starting soil moisture conditions, with all cases indicating that on 1 March 2008 and 2009 , just before the planting dates of each season, the root zone could be assumed to be at field capacity due to cumulative precipitations of 310 and $370 \mathrm{~mm}$ during the winters of 2008 and 2009, respectively. In a similar way, the soil layer depth was assumed to be at field capacity on 15 December 2008 in the wheat field.

\subsubsection{Meteorological measurements}

Daily and semi-hourly weather data for both sites were provided by two meteorological stations belonging to the 
Table 3. Sensor, number of selected pure pixels (PP) for each field/date and dates (day of year and day after emergency) used for monitoring corn and wheat fields during 2008 and 2009 growing seasons.

\begin{tabular}{|c|c|c|c|c|c|c|c|c|c|}
\hline \multicolumn{5}{|c|}{ Corn } & \multicolumn{5}{|c|}{ Wheat } \\
\hline \multicolumn{2}{|c|}{2008 growing season } & \multicolumn{3}{|c|}{2009 growing season } & \multicolumn{2}{|c|}{2009 growing season } & \multicolumn{3}{|c|}{2009 growing season } \\
\hline DOY(DAE) & Sensor* & DOY(DAE) & Sensor & PP & DOY(DAE) & Sensor* & DOY(DAE) & Sensor & PP \\
\hline $91(9)$ & ASD & $67(0)$ & ETM+off (L7) & 10 & $43(40)$ & ASD & $11(8)$ & TM (L5) & 4 \\
\hline $105(23)$ & ASD & $99(20)$ & ETM+off (L7) & 9 & $56(53)$ & ASD & $43(40)$ & TM (L5) & 4 \\
\hline $115(33)$ & ASD & $123(44)$ & TM (L5) & 39 & $71(68)$ & ASD & $67(64)$ & ETM+off (L7) & 4 \\
\hline $143(61)$ & ASD & $147(68)$ & ETM+off (L7) & 40 & $78(75)$ & ASD & $99(96)$ & ETM+off (L7) & 4 \\
\hline $158(76)$ & ASD & $163(84)$ & ETM+off (L7) & 38 & $96(93)$ & ASD & $123(120)$ & TM (L5) & 4 \\
\hline $169(87)$ & ASD & 171(92) & TM (L5) & 40 & $113(110)$ & ASD & $147(144)$ & ETM+off (L7) & 4 \\
\hline $185(103)$ & ASD & $203(124)$ & TM (L5) & 41 & 125 (122) & ASD & $163(160)$ & ETM+off (L7) & 4 \\
\hline $200(118)$ & ASD & $219(140)$ & TM (L5) & 39 & 139 (136) & ASD & $171(168)$ & TM (L5) & 4 \\
\hline $217(135)$ & ASD & $227(148)$ & ETM+off (L7) & 29 & 175 (172) & ASD & & & \\
\hline $233(151)$ & ASD & $235(156)$ & TM (L5) & 40 & $178(175)$ & ASD & & & \\
\hline 261(179) & ASD & $243(164)$ & ETM+off (L7) & 11 & $184(181)$ & ASD & & & \\
\hline
\end{tabular}

* ASD $=$ Field measurements with a hand-held radiometer ASD-FieldSpec.

Agroclimatic Information Network of Andalusia (RIA) (Gavilán et al., 2008), with one station located inside the Bembezar Irrigation Scheme, and the second one at $100 \mathrm{~m}$ from the wheat plot. The stations are controlled by a CR10X datalogger (Campbell Scientific, Logan, UT) and are equipped with sensors to measure air temperature and relative humidity (HMP45C probe, Vaisala, Helsinki, Finland), solar radiation (pyranometer SP1110 Skye Instruments, Llandrindod Wells, UK), wind speed and direction (wind monitor 05103 , RM Young, Traverse City, MI) and rainfall (tipping bucket rain gauge ARG 100, Environmental Measurements Limited, Sunderland, UK).

\subsubsection{Spectral data acquisition and processing}

Field canopy reflectance measurements were performed using a hand-held radiometer (ASD-FieldSpec, Analytical Spectral Devices, Boulder, CO) over corn in 2008 season and wheat in 2009. The spectral range of the instrument, between 325 and $1075 \mathrm{~nm}$ (with a sampling interval of $1.6 \mathrm{~nm}$ ), covered the visible and near-infrared (NIR) regions of the spectrum required for computing the vegetation indices and overlapped Landsat red and NIR spectral bands. A fiber optic jumper cable with a field of view (FOV) of $25^{\circ}$ was used in this study. Twenty-point regularly distributed measurements were taken over each field of corn and wheat at midday and under cloudless conditions. A sampling scheme based on knowledge of the row spacing (pairs "on row and off row") was selected for measurements over corn, taking one measurement over the plant (on row) and the second halfway between adjacent rows (off row) at each point of measurement. The altitude of the sensor above the soil was $4.5 \mathrm{~m}$, resulting in a FOV diameter at the soil surface 2.7 times as large as the row spacing $(0.75 \mathrm{~m})$. The measurements over wheat were taken in accordance with a simple random sampling scheme with a sensor altitude above the soil of $2.2 \mathrm{~m}$ resulting in a FOV diameter at the soil surface 5.4 times as large as the row spacing $(0.18 \mathrm{~m})$. Six additional measurements were made over the weighing lysimeter surface inside the wheat experimental field. The reflectance spectrum was calculated as the ratio between the reflected and incident spectra on the canopy, obtaining the incident spectrum from the light reflected by a white reference panel close to a Lambertian surface (Spectralon, Labsphere, North Sutton, NH). Red and NIR reflectance values, required for SAVI calculation, were computed by averaging the reflectance values corresponding to Landsat 5 TM red and NIR spectral intervals (bands 3 and 4) using the spectral response function of each TM band. All the spatially distributed SAVI data were averaged for each measurement day and field.

Satellite remote data were provided by TM and ETM+ sensors carried on board LANDSAT 5 and 7, during the 2009 corn and wheat seasons. All cloudless satellite images for both growing periods (a total of 13 images) were calibrated and geometrically and atmospherically corrected. The geometric correction was applied using reference ground control points acquired from a 1-m resolution ortho-photograph taken in 2004. At-surface reflectance was obtained from the correction of the shortwave bands of the images using the atmospheric radiative transfer model MODTRAN 4 (Berk et al., 1998). SAVI maps were calculated using the red and NIR reflectance bands for each Landsat image. Average SAVI values were extracted for each study field and the changes in SAVI over time were obtained by linear interpolation of the SAVI values from each image. The Landsat 7 ETM+ scan line corrector (SLC) failed on 31 May 2003, causing the 
scanning pattern to exhibit wedge-shaped scan-to-scan gaps. However, the ETM+ has continued to acquire data with the SLC powered off, leading to images that lack approximately 22 percent of the normal scene area (Storey et al., 2005). When some of these gaps fell within the experimental plots, their values were eliminated from the calculations.

A comparison between satellite-derived and groundderived SAVI was performed to evaluate the ability of satellite imagery to reproduce field measurements and successfully extrapolate field results to a larger scale. The estimates of SAVI derived from the Landsat-5 and 7 imagery were compared with SAVI values calculated from ground radiometry at the wheat experiment site (Table 3). The change over time in ground-derived SAVI was obtained by linear interpolation of the values of SAVI calculated from the radiometric measurements. Seven 2009 cloudless Landsat-5 and Landsat-7 images, overlapping the spectral measurement period, were used for this comparison.

A list of the sensors and dates used throughout the study for both crops is shown in Table 3.

\subsection{Validation data}

The model was validated using field measurements of soil moisture and ET. ET was measured using two different instrumentation sets: an eddy covariance system (EC) mounted on a micrometeorological flux tower, and a weighing lysimeter.

\subsubsection{Eddy covariance measurements and adjustment of turbulent fluxes}

Half-hourly sensible $(H)$ and latent (LE) heat fluxes over the corn plot were measured using an eddy covariance system consisting of a datalogger CR23X (Campbell Scientific), a three-axis sonic anemometer CSAT3 (Campbell Scientific), a fine thermocouple (model 127, chromel-constantan $0.013 \mathrm{~mm}$ diameter) attached to the anemometer, a krypton hygrometer KH20 (Campbell Scientific), a net radiometer Q7.1 (Radiation and Energy Balance Systems, Seattle, WA), two soil heat flux plates HFP01 (Hukseflux Thermal Sensors, Delft, The Netherlands) and four parallel soil thermocouples (TCAV). The distance between the sonic anemometer and the hygrometer measuring paths was $0.20 \mathrm{~m}$, and both were located at a height of $z=1.5 \mathrm{~m}$, above the canopy. As the crop height changed along the season, the height of the instruments was checked twice a week and changed whenever necessary. Sampling frequency was $10 \mathrm{~Hz}$. Fetch was at least $200 \mathrm{~m}$ in all directions. Corrections were applied to latent heat flux to account for air density fluctuations due to heat and vapor transfer (Webb et al., 1980; Tanner et al., 1993) and $\mathrm{O}_{2}$ radiation absorption (Tanner et al., 1993). The net radiometer was located $1.5 \mathrm{~m}$ above the canopy and net radiation data $\left(R_{\mathrm{n}}\right)$ were corrected for wind speed measured with the sonic anemometer according to the manu- facturer's recommendations. Soil heat flux $(G)$ was determined at two locations (within the row and midway between rows). The combination method (Fuchs and Tanner, 1967) was employed, using the measurement of soil thermocouples at 0.02 and $0.06 \mathrm{~m}$ and heat flux measured with the soil heat flux plates at $0.08 \mathrm{~m}$. Measurements of $R_{\mathrm{n}}$ and $G$ were performed at 10 s intervals and the mean reading was recorded half-hourly. The system was installed on the corn field between 28 April and 4 September 2008 and from 16 May until 29 August 2009, measuring continuously except on days with more than $0.2 \mathrm{~mm}$ of rain. A total of 96 complete days of eddy covariance measurements were collected during each growing season.

Detailed studies have shown how the eddy covariance technique underestimates turbulent fluxes, a finding that has been attributed to many different factors (Massman and Lee, 2002). Twine et al. (2000) compared different energybalance closures; EC measurement of $H$ and LE fluxes can be adjusted for closure, maintaining the Bowen ratio or forcing closure, assuming that $H$ is accurately measured and solving LE as a residual to the energy balance equation (LE $\left.=R_{n}-H-G\right)$. Brotzge and Crawford (2003) suggested residual LE closure as the best eddy covariance approach because the Bowen ratio technique tends to underestimate LE under highly evaporative conditions. We therefore calculated daily ET values by forcing closure of the energy balance using the residual-LE closure method, and an average closure of $80 \%$ was obtained.

\subsubsection{Weighing lysimeter}

Wheat ET was measured by a weighing lysimeter located in the center of the plot. The surface dimensions of the lysimeter tank are $2 \times 3 \mathrm{~m}^{2}$ and the depth is $1.5 \mathrm{~m}$. It is supported by a counter-weighted platform scale capable of detecting changes in weight of about $0.1 \mathrm{~kg}$ (equivalent to $0.02 \mathrm{~mm}$ water depth over the lysimeter surface). The lysimeter weight was sensed by a load cell (model TSF-P, Epel Industrial S.A., Alcala Guadaira, Spain) connected to a Datalogger CR10X (Campbell Scientific) and set to measure semi-hourly ET. Daily changes in mass $(\mathrm{kg})$ were converted to equivalent water depths $(\mathrm{mm})$ to obtain daily ET. The outputs were obtained as the average of 120 readings taken every $2 \mathrm{~s}$ over a 4-min period centered at the respective sampling times, so that fluctuations in weight due to wind friction on the lysimeter surface were smoothed (Berengena and Gavilán, 2005). Only measured ET from days with precipitation below 0.2 $\mathrm{mm}$ were used for comparison purposes. During the dataacquisition period (17 January to 25 June 2009) the lysimeter was drained twice (DOY 42 and 76), on neither of which days its measurements were used. A total of 112 days of lysimeter-measured ET were available for this study. 
Table 4. Sensitivity analysis parameters: reference values and ranges.

\begin{tabular}{l|rr|rr}
\hline \multirow{2}{*}{ Parameter } & \multicolumn{2}{|c|}{ Corn (2008-2009) } & \multicolumn{2}{|c}{ Wheat (2009) } \\
& Reference value & Simulated range & Reference value & Simulated range \\
\hline Maximum effective root depth (m) & 1.35 & $1.08-1.62$ & 1.25 & $1-1.5$ \\
Minimun effective root depth (m) & 0.3 & $0.1-0.5$ & 0.3 & $0.1-0.5$ \\
TEW (mm) & 21.5 & $17.2-25.8$ & 21.5 & $17.2-25.8$ \\
\hline
\end{tabular}

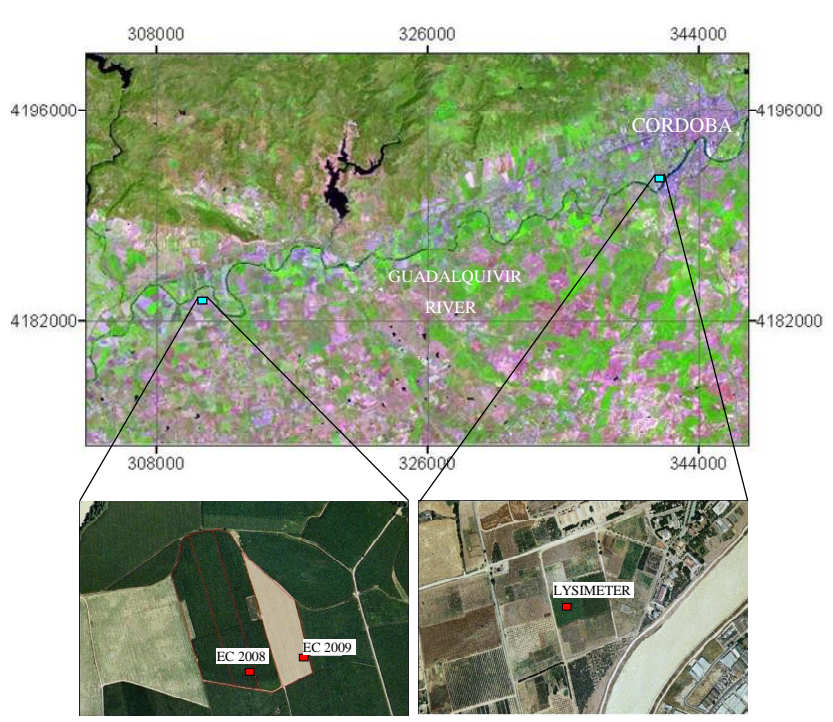

Fig. 1. A mid-infrared (band 5), near-infrared (band 4) and red (band 3) composite of the Landsat TM-5 image (3 May 2009; DOY 123) and a high resolution ortho-photograph (2004) showing the fields that contained the eddy covariance (EC) flux stations (2008 and 2009) and the weighing lysimeter (2009).

\subsubsection{Soil water content}

Soil water content was calculated as the difference between wet and dry weight of soil samples taken at intervals of 9-19 days throughout the wheat and corn-growing season. Four randomly distributed samples were taken each measurement day. The samples were taken at a depth of $120 \mathrm{~cm}$ and were extracted as $30 \mathrm{~cm}$-deep layers. The direct weight of these samples represented the wet weight. The samples were placed in an oven at $105^{\circ} \mathrm{C}$ for two days to obtain the dry weight.

\subsection{Sensitivity analysis}

A sensitivity analysis was performed to clarify, for this particular application of the model, the range of accuracy required for several input parameters involved in the calculation of the amount of water available for evaporation. A simple parameter perturbation (Chapra, 1997) was applied here, by varying each model parameter while holding all the other terms constant. The corresponding variations of the output variable reflected the sensitivity of the solution to the varied parameter.

The seasonal evapotranspiration $\left(\mathrm{ET}_{t}, \mathrm{~mm}\right)$ was selected as output variable and three parameters of the model affecting $\mathrm{ET}_{t}$; maximum effective root depth $\left(Z_{\mathrm{rmax}}\right)$, minimum effective root depth $\left(Z_{\mathrm{rmin}}\right)$ and TEW were selected to be analysed during the 2008 and 2009 corn and 2009 wheat seasons. The simulated $\mathrm{ET}_{t}$ was compared with a reference simulated seasonal evapotranspiration $\left(\mathrm{ET}_{\text {tref }}\right)$. The reference values of TEW and $Z_{\text {rmax }}$ were obtained from the central value of the intervals recommended by Allen et al. (1998) for silt loam soil and wheat and corn crops, respectively. Parameter reference values were varied by $\pm 10 \%$, until they reached similar values to the intervals recommended by Allen et al. (1998). The reference $Z_{\text {rmin }}$ was 0.3 , the value suggested by the FAO Aquacrop model (Steduto et al., 2009; Raes et al., 2009; Hsiao et al., 2009), which is designed to predict attainable yield based on the available water supply. Little attention has been paid to this parameter in previous studies, and the uncertainty about the variation interval led us to increase the earlier range of variation in the reference value, using intervals of $\pm 33 \%$ within limits of 0.1 and $0.5 \mathrm{~m}$. Table 4 shows the range of values used in this sensitivity analysis.

\section{Results and discussion}

\subsection{Comparison between satellite-derived and ground-derived vegetation indices}

Several studies (Moran et al., 1992, 1995; Liang et al., 2002; González-Dugo and Mateos, 2008) have evaluated the accuracy of atmospheric correction algorithms by comparing the retrieved satellite reflectance with ground-based or aircraftbased radiometric measurements and vegetation indices obtained from various sensors. In this study, we compared VIs obtained from Landsat imagery (5 and 7) and a handheld radiometer (ASD-FieldSpec). Satellite-derived SAVI and ground-derived SAVI obtained at the wheat experiment (Fig. 2) agreed with a coefficient of determination $\left(r^{2}\right)$ of 0.98 and a root mean square difference (RMSD) of 0.025 . Specific limitations pointed out by Jackson and Huete (1991) when using VI obtained from different sensors, such as the 


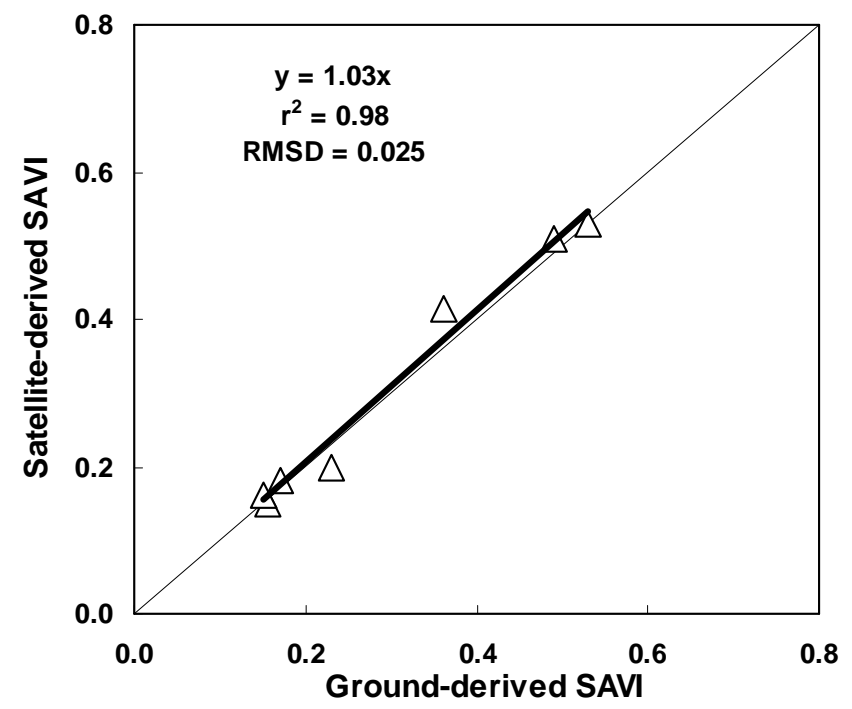

Fig. 2. Satellite-derived soil adjusted vegetation index (SAVI) vs. ground-derived SAVI at the wheat experiment. The thin solid diagonal line represents the 1:1 line, while the dark line segment represents the linear regression through the points.

use of processed data (reflectance) as input variable and the atmospheric correction of satellite data, have been taken into account in this comparison.

\subsection{ET estimation using field radiometry data}

Daily measured ET fluxes were first compared with daily estimated ET using the hand-held radiometer measurements to assess the basal crop coefficient. Figure 3 shows daily estimated ET from the model and daily measured ET in corn (2008) using the eddy covariance system, and wheat (2009) using the weighing lysimeter.

The performance of the model was measured using the RMSD between estimated and measured ET values and the coefficient of determination. RMSD values of 0.8 and $0.67 \mathrm{~mm} \mathrm{~d}^{-1}$ were obtained for corn and wheat respectively. These values are slightly higher than those presented by other authors in earlier studies of the same crops. Er-Raki et al. (2007) and González-Dugo et al. (2009) found differences close to $0.5 \mathrm{~mm} \mathrm{~d}^{-1}$. The poorer performance found here does not appear to be significant and could be explained by differences in meteorological data quality and/or management practices. The model showed a general trend to overestimate daily ET of 8 and $11 \%$ in corn and wheat respectively. A higher dispersion and a reverse of this trend can be observed in corn for low ET values, suggesting that at the beginning of the growing cycle, when crop groundcover is lower, field-measured SAVI may have been less representative of average values for the area covering the flux tower footprint than those measured under conditions of greater vegetation ground coverage. This problem was
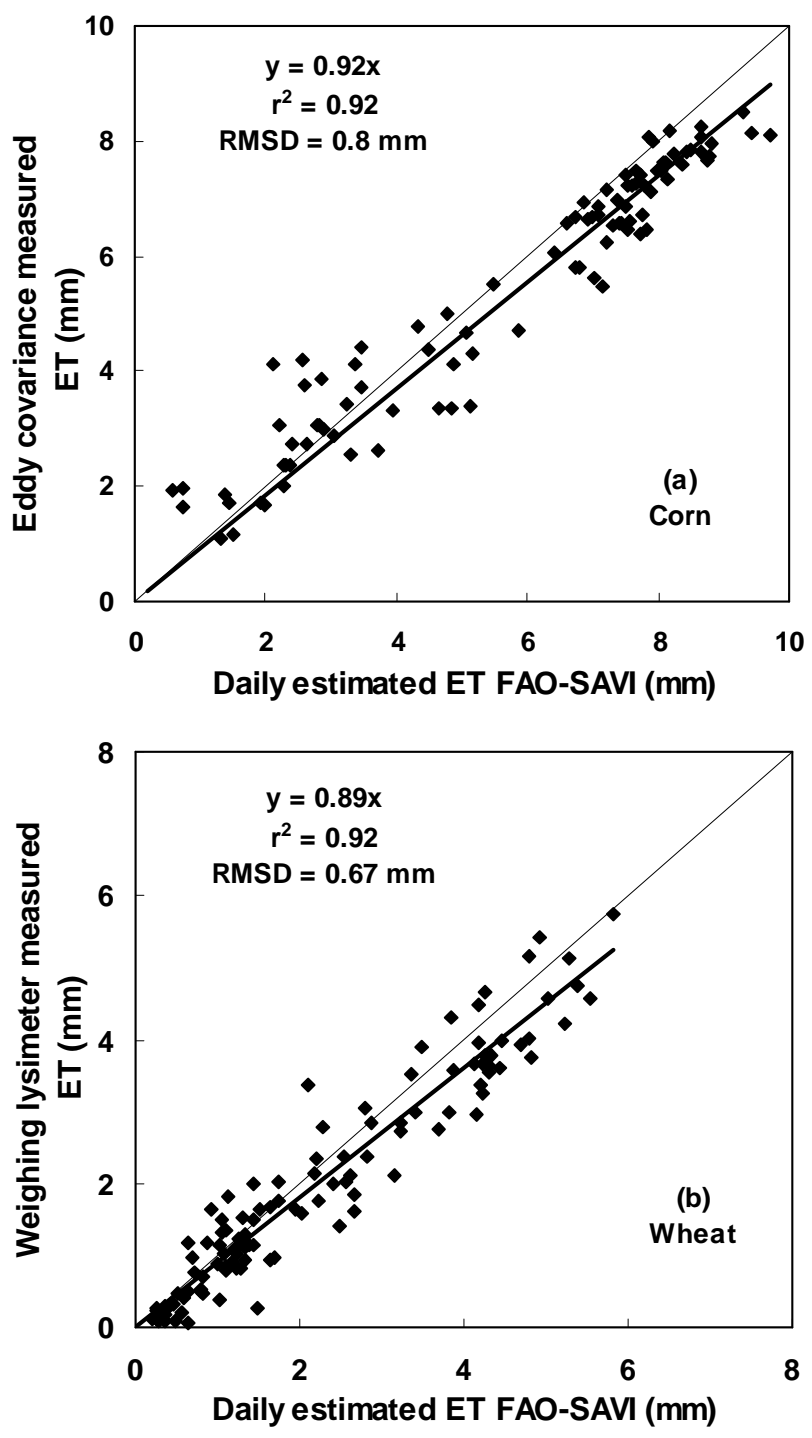

Fig. 3. Daily measured and estimated ET for corn (2008) (a) and wheat (2009) (b) using a radiometer-estimated $K_{\mathrm{cb}}$. The thin solid diagonal line represents the 1:1 line, while the dark line segment represents the linear regression through the points.

not encountered with wheat, where six radiometric measurements were taken over the lysimeter area (plot size $6 \mathrm{~m}^{2}$ ). The coefficients of determination $\left(r^{2}\right)$ were of 0.92 for both crops, slightly higher than the good correlations presented by other authors for extensive and woody crops, including corn, $r^{2}=0.70$ (González-Dugo et al., 2009), wheat, $r^{2}=0.64-$ 0.86 (Er-Raki et al., 2007) and vines, $r^{2}=0.86$ (Campos et al., 2010). The soil water-content measurements were used to validate the water balance employed in the calculation of $K_{\mathrm{e}}$ and $K_{\mathrm{s}}$. This may be regarded as an alternative validation of the complete ET computing procedure. Figure 4 shows the comparison between the model-estimated root-zone water deficit and the real deficit obtained from soil samples, 

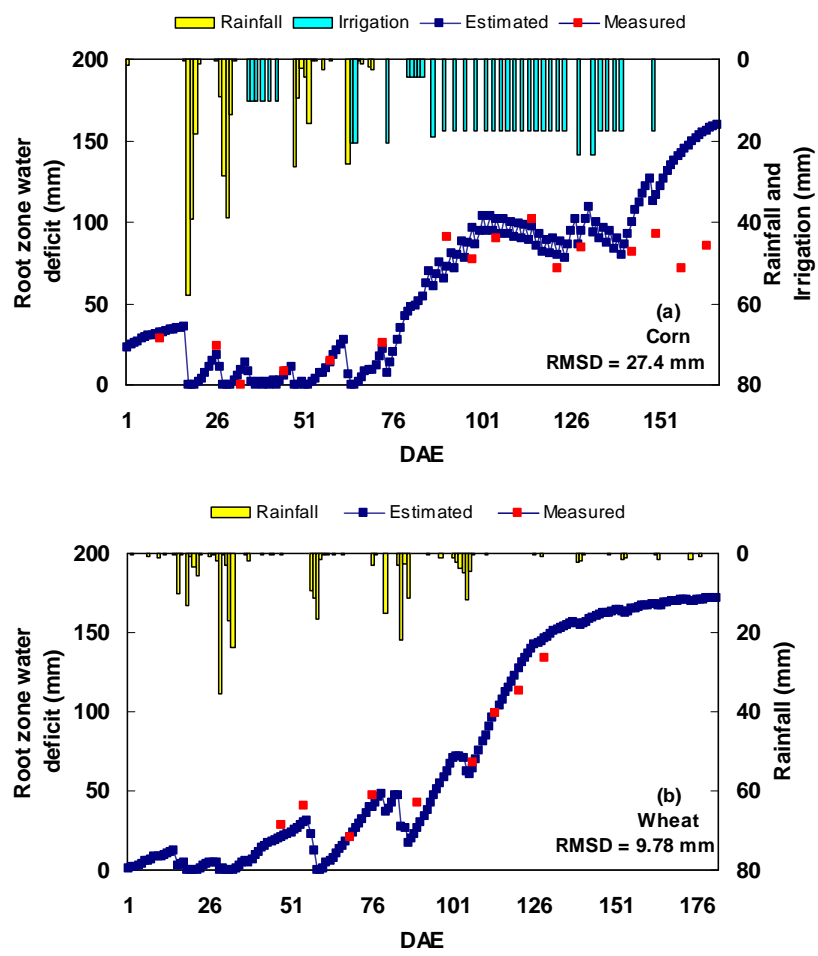

Fig. 4. Daily measured and estimated root zone water deficit for corn (2008) (a) and wheat (2009) (b) using a radiometer-estimated $K_{\mathrm{cb}}$. (DAE = day after emergence).

where a significant agreement exists between the estimated and measured deficit in wheat $(\mathrm{RMSD}=9.78 \mathrm{~mm})$. However, there are some discrepancies at the end of the corn season during crop senescence. The trend in the estimated deficit matched reasonably well the measured data, irrespective of whether particular points, that will require further analysis, correspond to the general behavior of the model.

\subsection{Satellite scale ET assessment}

TM and ETM+ sensors were used to derive the SAVI index as periodic input to the FAO56 model. The comparison between daily estimated and measured ET is shown in Fig. 5. An RMSD of $1 \mathrm{~mm} \mathrm{~d}^{-1}$ was obtained for corn during this second season. Both RMSD and the $9 \%$ overestimate were similar but slightly higher than 2008 corn season values. The computed SAVI represented an average of 7.4 ha, discounting field-border pixels, and taking into account the variability within the field. An RMSD of $0.5 \mathrm{~mm} \mathrm{~d}^{-1}$ and $r^{2}=0.9$ was obtained for wheat using satellite inputs. The model showed a tendency to overestimate ET by six percent. The comparison between modeled root-zone water deficit values and measured values at this scale is shown in Fig. 6. The reasonable agreement during most of the time in the corn and wheat seasons indicates that the model is able to estimate the root-zone water deficit under both rain-fed and irrigated con-
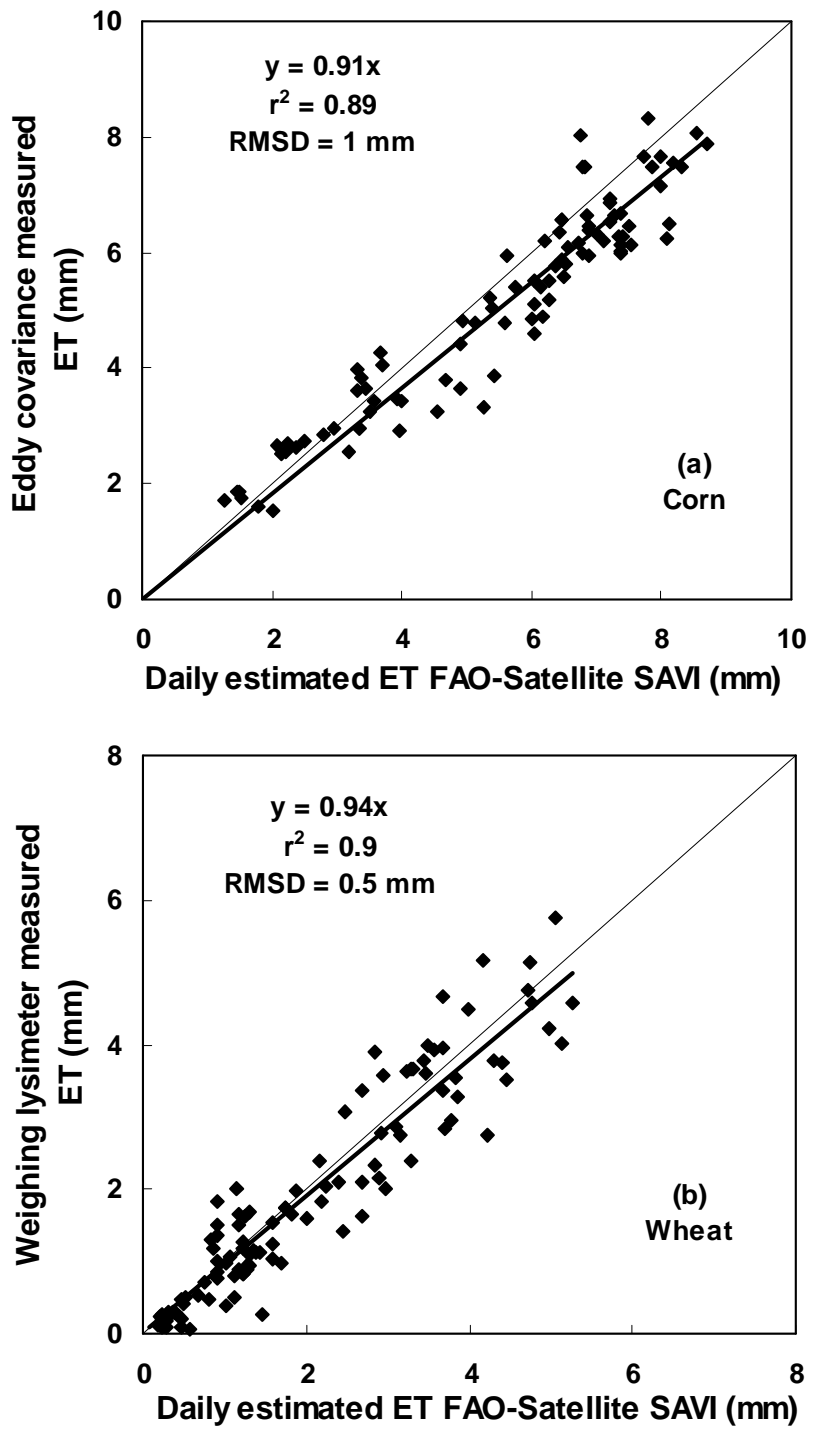

Fig. 5. Daily measured and estimated ET for corn (2009) (a) and wheat (2009) (b) using a satellite-estimated $K_{\mathrm{cb}}$. The thin solid diagonal line represents the 1:1 line, while the dark line segment represents the linear regression through the points.

ditions. However, some discrepancies similar to those observed during 2008 corn senescence were found at the end of the 2009 season. For irrigated crops, there is some uncertainly associated with the amount of irrigation water applied due to problems arising from low uniformity, poor maintenance of the irrigation system or problems with the pipes and drippers during the growing season, which are common under field conditions. Beyond the uncertainly of applied water at the end of the season, discrepancies during the senescence in both years could indicate that the model is not properly estimating corn transpiration during the R6 growth stage, issue that will require further attention in the future. 

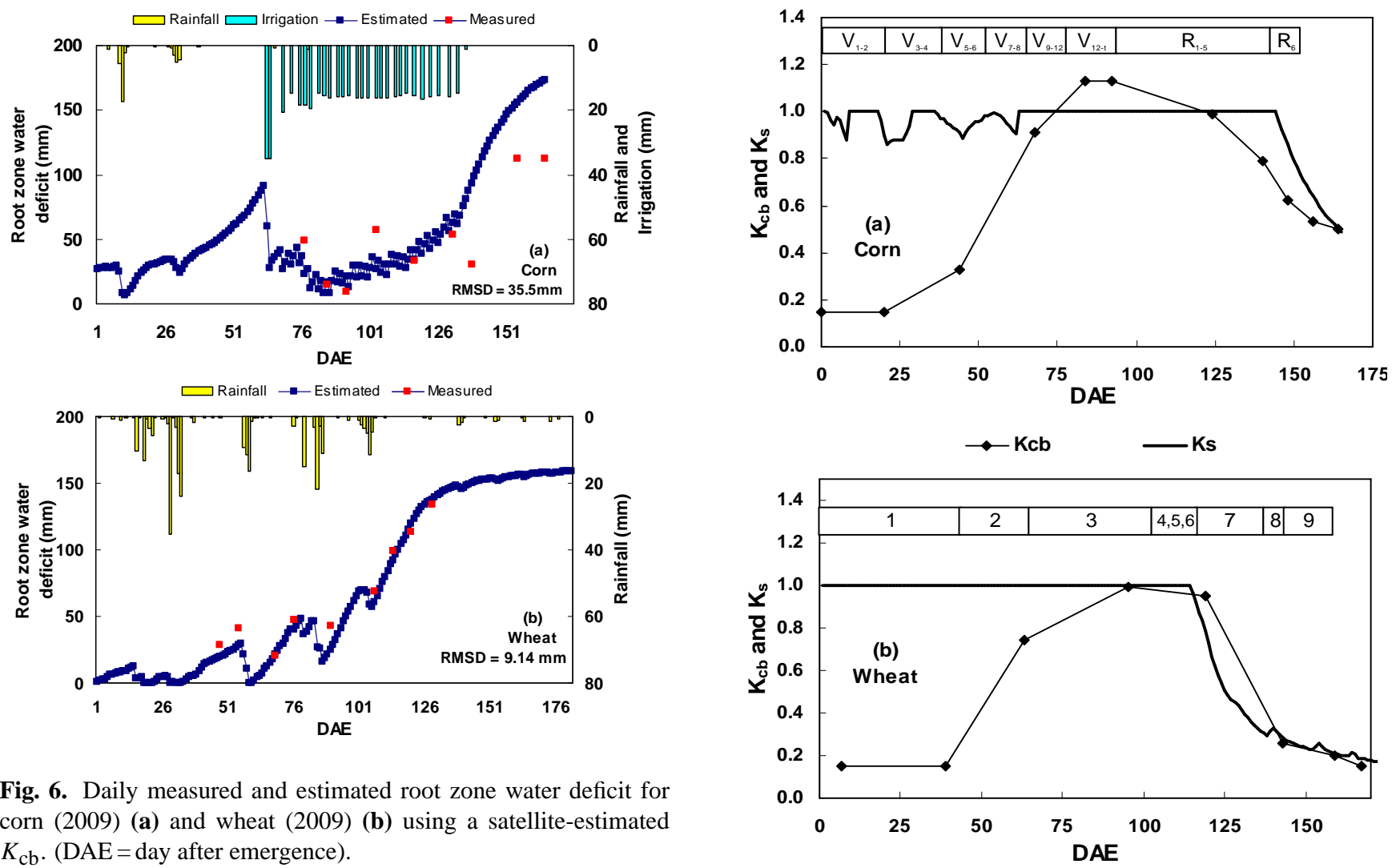

Fig. 6. Daily measured and estimated root zone water deficit for corn (2009) (a) and wheat (2009) (b) using a satellite-estimated $K_{\mathrm{cb}} .(\mathrm{DAE}=$ day after emergence).

\subsection{Water stress monitoring of crops}

A further step in irrigation water management is the monitoring and control of crop water stress, essential to guarantee high yields under conditions of water scarcity. This is also required in deficit irrigation systems and to improve fruit or grain quality in certain crops. The degree of water stress can be approximated by following the development of modeled $K_{\mathrm{S}}$ coefficients. This approach is supported by the studies of Colaizzi et al. (2003a,b) who pointed out the relationships between the $K_{\mathrm{S}}$ coefficient and the temperature-based Water Deficit Index (WDI, Moran et al., 1994) and Crop Water Stress Index (CWSI, Jackson et al., 1981). Only satellitebased campaigns were used in our analysis, due to the better representativeness of satellite-derived VIs of field crop variability. According to FAO-56 methodology, $K_{\mathrm{S}}$ values lower than unity indicates that the crop is suffering water stress. Figure 7 shows the stress and basal crop coefficients for 2009 wheat and corn throughout the growing season. Five periods of water stress can be observed in Fig. 7a for irrigated corn. The four first periods were mild, and they occurred during the rapid growth stage (April-May), before the beginning of irrigation (22 May 2009). According to the growth dynamics of the crop, represented by $K_{\mathrm{cb}}$ curve in Fig. $7 \mathrm{a}$, and the reasonably good tolerance of corn plants to soil-water stress during this stage (Doorenbos and Kassam, 1979), these periods had no impact on the final yield. During the reproductive

Fig. 7. Satellite-estimated basal crop coefficient and stress coefficient for corn (2009) (a) and wheat (2009) (b). Ritchie's (Ritchie and Hanway, 1982) and Zadok's stages for corn and wheat, respectively, are also shown.

stage, the most critical period, enough water was available for the plant. The last period of water stress was observed during the late season, 15 days before harvest. This was the consequence of a common management practice in this area, where most local farmers apply the final irrigation 15 to 20 days before the grain ripens, in order to save water and given the relative tolerance of the crop to water stress during maturity (Doorenbos and Kassam, 1979). However, this dry period was too prolonged and probably contributed to a reduction in yield that in this particular field was around $20 \%$ lower than the $12500 \mathrm{~kg} \mathrm{ha}^{-1}$ local average (CAP, 2009).

The water stress for wheat affected the entire grain-filling stage, Fig. 7b, corresponding to Zadoks stages 7-9 (Zadok et al., 1974). A lack of water at these stages is known to have a significant effect on grain filling, resulting in lower yields (Rawson and Gómez, 2000). The cumulative soil water content during the winter was not enough to satisfy the evapotranspiration demand of the final two months of the growing season. In this case, the harvested yield of $2100 \mathrm{~kg} \mathrm{ha}^{-1}$ was $28 \%$ lower than the figure provided by regional agriculture statistics for wheat (CAP, 2009). 


\subsection{Sensitivity analysis}

The results of the sensitivity analysis for the three monitored growing seasons are shown in Fig. 8. Relative values are presented to facilitate comparisons between parameters and seasons. The simulated $\mathrm{ET}_{\text {tref }}$ values were 803 and 712 for corn in 2008 and 2009, respectively, and $342 \mathrm{~mm}$ for wheat. In all cases, variations in $\mathrm{ET}_{t}$ were more significant for $Z_{\mathrm{rmax}}$ than for $Z_{\mathrm{rmin}}$ or TEW, with an average variation of $3.8 \%$ for $20 \%$ variation in the $Z_{\text {rmax }}$ parameter, compared to $\mathrm{ET}_{t}$ variations of $0.2 \%$ and $0.5 \%$ for the same change in the values of the other two parameters.

The sensitivity of the model to $Z_{\mathrm{rmax}}$ differed slightly between the corn and wheat simulations, with a higher variation for rainfed wheat. The effect of $Z_{\mathrm{rmax}}$ on $\mathrm{ET}_{t}$ was higher for wheat, with an average variation of $7.2 \%$ for a $20 \%$ of change in the reference parameter value. However, the maximum $\mathrm{ET}_{t}$ variations under irrigated conditions were 2 and $3.1 \%$ in 2008 and 2009 respectively, for the same parameter disturbance. An increase or decrease in $Z_{\mathrm{rmax}}$ significantly affects the calculation of the control volume for the soil water balance and thus the daily water storage capacity. The influence on ET is more obvious under conditions of water stress and when the soil water content is close to the threshold value that determines the beginning of stress, starting the stress coefficient calculation and the reduction of transpiration. Rainfed wheat suffered a prolonged period of water stress that lasted for 67 days at the end of the season, while only 15 days before harvest was observed for corn in both seasons, a difference that may explain the different effect of $Z_{\mathrm{rmax}}$ variation on $\mathrm{ET}_{t}$.

The effects of variations in $Z_{\mathrm{rmin}}$ on $\mathrm{ET}_{t}$ estimation were very limited for both crops. $Z_{\text {rmin }}$ influences the water balance until $Z_{\text {rmax }}$ is reached and its effect is probably more significant on daily ET during the initial growth stage. However, a stronger effect was observed for corn (1.9 of $\mathrm{ET}_{t}$ variation on average for $66 \%$ of parameter variation), in which water was scarce during the stage of rapid growth, than for wheat ( 0.55 for $66 \%$ of variation). TEW appeared to have a negligible effect on $\mathrm{ET}_{t}$ under both rainfed and irrigated conditions. The maximum variations of $\mathrm{ET}_{t}$ with respect to $\mathrm{ET}_{\text {tref }}$ were 0.7 and $0.3 \%$ for corn in 2008 and 2009, respectively, and $0.8 \%$ for wheat.

\section{Conclusions}

The results of daily ET obtained for both crops with crop coefficients calculated using field and satellite derived remote vegetation indices were generally consistent with measurements. The modeled results compared well with both ET measurement systems EC and lysimeter, showing average overestimates of $8 \%$ on daily ET. The model was also capable of tracing a soil water deficit curve in agreement with point measurements of soil moisture.
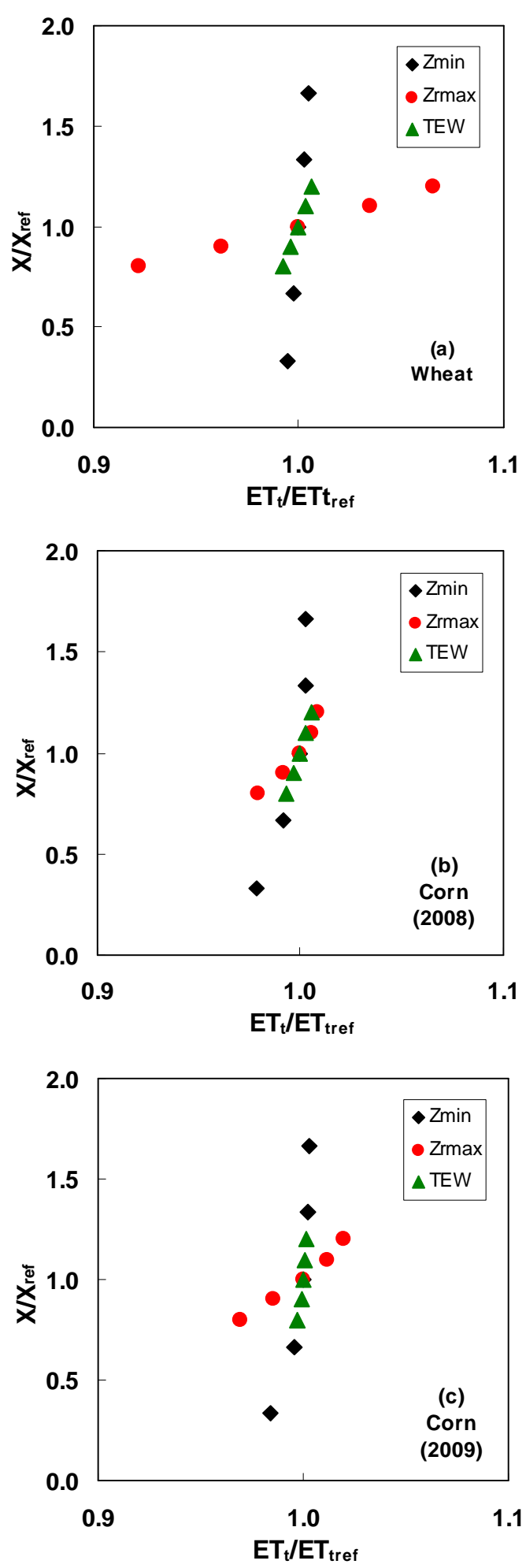

Fig. 8. $\mathrm{ET}_{t}$ with respect to $\mathrm{ET}_{\text {tref }}$ for variations in maximum effective root depth $\left(Z_{\max }\right)$, minimum effective root depth $\left(Z_{\min }\right)$ and TEW, for wheat 2009 season (a) and corn 2008 (b) and 2009 (c) seasons. 
The use of satellite-borne sensors permitted low-cost, large-scale acquisition of distributed vegetation indices, without significant loss of accuracy in the final ET estimation, thus avoiding problems of representative field measurements for low plant ground coverage. The extension of the method to larger areas using satellite inputs is hindered by the need for a daily water balance that requires accurate soil and irrigation information, which is difficult to gather on a large scale. However, Díaz et al. (2009) have proposed a simplification of water balance calculating a synthetic crop coefficient that accounts for the main effects of rain and irrigation soil wetting on ET that could permit an upscaling of this model, reducing the data requirements.

Analysis of trends in the stress coefficient derived from the water balance provided valuable information about the use of water in both crops along the growing season, helped to quantify the incidence of water stress during individual growth stages and provided insights into its relationship with final yields under both rainfed and irrigated conditions.

This methodology can be used to perform water stress analyses and to decide when and how much to irrigate. The combination of remote sensing-derived basal crop coefficients with the FAO methodology could be an important tool for estimating water requirements and improve water management at irrigation-scheme and basin scales.

Acknowledgements. The authors are grateful for the support of CICE-Junta de Andalucía through the project P06-AGR-2317 and of the Spanish Ministry of Science and Innovation (EHBE project, CGL-2008-04047). We also wish to thank Paco Toscano and Alfonso Grande for providing corn management data.

Edited by: E. Morin

\section{References}

Allen, R. G., Pereira, L. S., Raes, D., and Smith, A. R.: Crop evapotranspiration: Guidelines for computing crop requirements. Irrigation and Drainage Paper No. 56 FAO, Rome, 1998.

Allen, R. G., Tasumi, M., and Trezza, R.: Satellite-based energy balance for mapping evapotranspiration with internalized calibration (METRIC)-Model, J. Irrig. Drain. E-ASCE, 133(4), 380394, 2007.

Anderson, M. C., Kustas, W. P., and Norman, J. M.: Upscaling flux observations from local to continental scales using thermal remote sensing, Agron. J., 99, 240-254, 2007.

Asrar, G., Mineny, R. B., and Kanemasu, E. T.: Estimation of plant-canopy attributes from spectral reflectance measurements, in "Theory and applications of optical remote sensing", edited by: Asrar, G., Chichester: John Wiley and Sons, 252-292, 1989.

Baret, F. and Guyot, G.: Potentials and limits of vegetation indices for LAI and APAR assessment, Remote Sens. Environ., 35, 161173,1991

Bausch, W. C. and Neale, C. M. U.: Crop coefficients derived from reflected canopy radiation: a concept Trans, ASAE, 30(3), 703$709,1987$.
Berengena, J. and Gavilán, P.: Reference evapotranspiration estimation in a highly advective semiarid environment, J. Irrig. Drain. E., 131(2), 147-163, 2005.

Berk, A., Bernstein, L. S., Anderson, G. P., Acharya, P. K., Robertson, D. C., Chetwynd, J. H., and Adler-Golden, S. M.: MODTRAN cloud and multiple scattering upgrades with application to AVIRIS, Remote Sens. Environ., 65, 367-375, 1998.

Brotzge, J. A. and Crawford, K. C.: Examination of the surface energy budget: A comparison of eddy correlation and Bowen ratio measurement systems, J. Hydrometeorol., 4, 160-178, 2003.

Calera, A., González-Piqueras, J., and Meliá, J.: Monitoring barley and corn growth from remote sensing data at field scale, Int. J. Remote Sens., 25, 97-109, 2004.

Campos, I., Neale, C. M. U., Calera, A., Balbontin, C., and González-Piqueras, J.: Assessing satellite-based basal crop coefficients for irrigated grapes (Vitis vinifera L.), Agr. Water Manage., 97, 1760-1768, 2010.

CAP: Crop yield annual statistics. [Online WWW], available:http://www.juntadeandalucia.es/agriculturaypesca/portal/ servicios/estadisticas/index.html, last access: October 2010, 2009.

Chapra, S. C.: Surface water-quality modelling, Mc-Graw-Hill, New York, 1997.

Charles, J., Godfray, J., Beddington, J. R., Crute, I. R., Haddad, L., Lawrence, D., Muir, J. F., Pretty, J., Robinson, S., Thomas, S. M., and Toulmin, C.: Food Security: The challenge of feeding 9 billion people, Science, 327, 812-818, 2010.

Choudhury, B. J., Ahmed, N. U., Idso, S. B., Reginato, R. J., and Daughtry, C. S. T.: Relations between evaporation coefficients and vegetation indeces studied by model simulations, Remote Sens. Environ., 50, 1-17, 1994.

Colaizzi, P. D., Barnes, E. M., Clarke, T. R., Choi, C. Y., Waller, P. M., Haberland, J., and Kostrzewski, M.: Water stress detection under high frequency sprinkler irrigation with water deficit index, J. Irrig. Drain. E-ASCE., 129(1), 36-43, 2003 a.

Colaizzi, P. D., Barnes, E. M., Clarke, T. R., Choi, C. Y., and Waller, P. M.: Estimating soil moisture under low frequency surface irrigation using crop water stress index, J. Irrig. Drain. E-ASCE., 129(1), 27-35, 2003b.

Díaz, A., González-Dugo, M.P., Escuin, S., Mateos, L., Cano, F., Cifuentes, V., Tirado, J. L., and Oyonarte, N.: Irrigation water use monitoring at watershed scale using series of high-resolution satellite images, in: Remote Sensing for Agriculture, Ecosystems and Hydrology. Proc. SPIE., edited by: Neale, C. M. U. and Maltese, A., Vol. 7472. Pág. 74720E-1, 2009.

Doorenbos, J. and Kassam, A. H.: Yield response to water, FAO Irrigation and Drainage, Paper $\mathrm{N}^{\mathrm{O}} 33$, FAO, Rome, 1979.

Doorenbos, J. and Pruitt, W. O.: Crop water requirement, FAO Irrigation and Drainage, Paper $N^{\circ}$ 24, FAO, Rome, 1977.

Duchemin, B., Hadria, R., and Er-Raki, S.: Monitoring wheat phenology and irrigation in central Morocco: On the use of relationships between evapotranspiration, crop coefficient, leaf area index and remotely-sensed vegetation indices, Agr. Water Manage., 79, 1-27, 2006.

Er-Raki, S., Chehbouni, A., Guemouria, N., Duchemin, B., Ezzahar, J., and Hadria, R.: Combining FAO-56 model and groundbased remote sensing to estimate water consumption of wheat crops in semi-arid regions, Agr. Water Manage., 87, 41-54, 2007. FAO: World Agriculture: Towards 2030/2050. Interim report. 
Prospects for food, nutrition, agriculture and major commodity groups, Rome, Italy, 2006.

Fuchs, M. and Tanner, C. B.: Evaporation from a drying soil, J. Appl. Meteorol., 6, 852-857, 1967.

Gavilán, P., Estévez, J., and Berengena, J.: Comparison of standardized reference evapotranspiration equations in southern Spain, J. Irrig. Drain. E., 134(1), 1-12, 2008.

Glenn, E., Huete, A., Nagler, P., and Nelson, S.: Relationship between remotely-sensed vegetation index, canopy attributes and plant physiological processes: what vegetation indices can and cannot tell us about the landscape, Sensors, 8(4), 2136-2160, 2008.

González-Dugo, M. P. and Mateos, L.: Spectral vegetation indices for benchmarking water productivity of irrigated cotton and sugarbeet crops, Agr. Water Manage., 95, 48-58, 2008.

González-Dugo, M. P., Neale, C. M. U., Mateos, L., Kustas, W. P., Prueger, J., Anderson, M. C., and Li, F.: A comparison of operational remote-sensing-based models for estimating crop evapotranspiration, Agr. Forest Meteorol., 149, 1843-1853, 2009.

Gonzalez-Piqueras, J., Calera Belmonte A., Gilabert, M. A., Cuesta García, A., and De la Cruz Tercero, F.: In: Estimation of crop coefficient by means of optimized vegetation indices for corn. Proceedings of the SPIE Congress, Barcelona, 8-11 September, p. 12, 2003.

Heilman, J. L., Heilman, W. E., and Moore, D. G.: Evaluating the crop coefficient using spectral reflectance, Agron. J., 74, 967971, 1982.

Hsiao, T. C., Stetuto, P., and Fereres, E.: A systematic and quantitative approach to improve water use efficiency in agriculture, Irrigation Sci., 25, 209-231, 2007.

Hsiao, T. C., Heng, L. K., Steduto, P., Rojas-Lara, B., Raes, D., and Fereres, E.: AquaCrop-The FAO Crop Model to Simulate Yield Response to Water: III. Parameterization and Testing for Maize, Agron. J., 101, 448-459, 2009.

Huete, A. R.: A soil-adjusted vegetation index (SAVI), Remote Sens. Environ., 25, 295-309, 1988.

Hunsaker, D. J., Pinter Jr., P. J., Barnes, E. M., and Kimball, B. A.: Estimating cotton evapotranspiration crop coefficient with a multispectral vegetation index, Irrigation Sci., 22, 95-104, 2003.

Hunsaker, D. J., Pinter, P. R. and Kimball, B. A.: Wheat basal crop coefficients determined by normalized difference vegetation index. Irrigation Sci., 24, 1-14, 2005.

Jackson, R. D., Idso, S. B., Regionato, R. J., and Pinter Jr., P. J.: Remotely sensed crop temperatures and reflectances as inputs to irrigation scheduling, in: Irrigation and Drainage Special Conference Proceedings, ASCE, Boise, N.Y., USA, 390-397, 1980.

Jackson, R. D., Idso, S. B., Regionato, R. J., and Pinter Jr., P.J.: Canopy temperatures as a crop water stress indicator, Water Resour. Res., 17, 1133-1138, 1981.

Jackson, R. D. and Huete, A. R.: Interpreting vegetation indices, Prev. Vet. Med., 11, 185-200, 1991.

Jayanthi, H., Neale, C. M. U., and Wright, J. L.: Development and validation of canopy reflectance-based crop coefficient for potato, Agr. Water Manage., 88(1-3), 235-246, 2007.

Liang, S., Fang, H., Morisette, J. T., Chen, M., Shuey, C. J., Wathall, C. J., and Daughtry, C. S. T.: Atmospheric correction of Landsat ETM+ Land surface Imagery: II. Validation and Applications, IEEE T. Geosci. Remote, 2002.

Moran, M. S., Clarke, T. R., Inoue, Y., and Vidal, A.: Estimating crop water deficit using the relation between surface-air temperature and spectral vegetation index, Remote Sens. Environ., 49, 246-263, 1994.

Moran, M. S., Jackson, R. D., Slater, P. N., and Teillet, P. M.: Evaluation of simplified procedures for retrieval of land surface reflectance factor from satellite sensor output, Remote Sens. Environ., 41, 169-184, 1992.

Moran, M. S., Jackson, R. D., Clarke, T. R., Qi, J., Cabot, F., Thome, K. J., and Markham, B. L.: Reflectance factor retrieval from Landsat TM and SPOT HRV data for bright and dark target, Remote Sens. Environ., 52, 218-230, 1995.

Neale, C. M. U., Bausch, W. C., and Heerman, D. F.: Development of reflectance-based crop coefficients for corn, Transactions of the ASAE, 32(4), 1891-1899, 1989.

Rawson, H. M. and Gómez, H.: Irrigated Wheat, FAO, Rome, Italy, 2000.

Raes, D., Steduto, P., Hsiao, T. C., and Fereres, E.: AquaCrop - The FAO Crop Model to Simulate Yield Response to Water: II. Main Algorithms and Software Description, Agron. J., 101, 438-447, 2009.

Rijsberman, F. R.: Water scarcity: fact or fiction?, Agr. Water Manage., 80, 5-22, 2006.

Ritchie, S. and Hanway, J. J.: How a corn plant develops. Iowa State University Technol. Spec. Report, 48 pp., 1982.

Schapp, M. G., Leij, F. J., and van Genuchten, M. Th.: "Rosetta: a computer program for estimating soil hydraulic parameters with hierarchical pedotransfer functions", J. Hydrol., 251(3), 163176, doi:10.1016/S0022-1694(01)00466-8, 2001.

Steduto, P., Hsiao, T. C., Raes, D., and Fereres, E.: AquaCropThe FAO Crop Model to Simulate Yield Response to Water: I. Concepts and Underlying Principles, Agron. J., 101, 426-437, 2009.

Storey, J., Scaramuzza, P., Schmidt, G., and Barsi, J.: Landsat 7 scan line corrector-off gap-filled product development. Pecora 16 "Global Priorities in Land Remote Sensing" conference proceedings (ASPRS), 2005.

Tanner, B. D., Swiatek, E., and Greene, J. P.: Density fluctuations and use of the krypton hygrometer in surface flux measurements, in: Proceedings of the National Conference on Irrigation and Drainage Engineering, edited by: Allen, R. G., and Neale, C. M. U., Park City, Utah, American Society of Civil Engineers, New York, 21-23 July 1993, pp105-112, 1993.

Teixeira, A. H. D. C., Bastiaanssen, W. G. M., Ahmad, M. D., and Bos, M. G.: Reviewing SEBAL input parameters for assessing evapotranspiration and water productivity for the Low-Middle São Francisco River basin, Brazil: Part B: Application to the regional scale, Agric. Forest Meteorol., 149, 477-490, 2009.

Twine, T. E., Kustas, W. P., Norman, J. M., Cook, D. R., Houser, P. R., Meyer, T. P., Prueger, J. H., Starks, P. J., and Wesley, M. L.: Correcting eddy-covariance flux underestimates over grassland, Agr. Forest Meteorol., 103, 279-300, 2000.

Webb, E. K., Pearman, G. I., and Leuning, R.: Corrections of flux measurements for density effects due to heat and water vapour transfer, Q. J. Roy. Meteor. Soc., 106, 85-110, 1980.

Wright, J. L.: New evapotranspiration crop coefficients, J. Irrig. Drain. Div., 108, 57-74, 1982.

Zadoks, J. C., Chang, T. T., and Konzak, C. F.: Decimal code for growth stages of cereals. Weed Res., 14(4), 415-421, 1974. 